\title{
Do We Need Protectionism?
}

This paper looks at trade protectionism in an attempt to determine whether mature economies entering the twentyfirst century need to protect their domestic producers from foreign competition. Part I reviews and analyzes the most common arguments that have been offered in support of protectionist policies over the last few centuries. Part II discusses some protectionist features of NAFTA and the recently concluded Uruguay Round of GATT to determine whether these provisions are in the best interests of the general public. Part III concludes that there is no need to protect domestic producers at the expense of the general public, and that the only trade policy that benefits the general public is one of total, immediate and unilateral free trade.

\section{Common Protectionist Arguments}

A number of arguments in favor of protectionism have been put forth over the centuries. ${ }^{1}$ But none of them will hold up to analysis if viewed from a total benefit perspective. All protectionist policies are merely forms of special interest legislation, since they protect some group of domestic producers at the expense of the general public.

One of the most frequently mentioned arguments, and one of the most plausible on the surface, is the infant industry argument. Basically, this argument states that protectionism is needed for a certain new industry only temporarily, until it can become mature enough to withstand foreign competition. Adam Smith advocated this form of protection in his Wealth of Nations (1776). Alexander Hamilton did so in his Report on Manufactures (1791). 
The main problem with this argument is that temporary protection tends to turn into permanent or long-term protection. Once an industry starts receiving protection, it becomes difficult or impossible to lift the protection at some later date. Interests become vested and entrenched. The result is that infant industries become midgets and never reach full height (Kindleberger; Corden). Even if protection does help an infant industry, protection is gained only by the diversion of resources from other industries, thus weakening them. If too many infant industries are protected, the fallacy of composition kicks in. In some instances, infant industry protection does not work even when applied only to a single industry (Krueger and Tuncer; Truett and Truett). The sugar industry in the United States has been an infant industry since 1816 . Its special status has allowed it to charge domestic consumers up to four times the world price for sugar.(Bovard; Novack).

A corollary to the infant industry argument is the breathing room argument. This argument holds that some mature industry needs temporary protection so it can have some breathing room to cut costs, retool and improve its technology. The auto, textile and steel industries are prone to use this argument. The problem is that such temporary measures like quotas and voluntary restraint agreements have not worked well in practice. The voluntary restraint agreement on autos between the United States and Japan during the early 1980s did not make U.S. automakers more competitive (Gable). Labor productivity in the steel industry has actually declined since "temporary" protection measures were introduced in 1969 (Gable). Murray Rothbard (1988) has called this argument the senile industry argument.

Another protectionist argument that Adam Smith supported was the national defense argument. For Smith, defense is more important than opulence. Stated from this perspective, the national defense argument seems difficult, if not impossible, to refute. But if one digs beneath the surface, cracks start to appear in the foundation.

The main problem with the national defense argument is that, in practice, many industries have used this argument to justify protection when, in fact, none is called for. 
The fruit, cheese, railroad, watch manufacturing, peanut, airline, truck and telephone industries have all used the national defense argument to plea for protection (Ekelund and Tollison; Curtiss)

Another problem with the argument is one of definition. What exactly is a strategic industry? Does anyone seriously think that some future war effort would be imperiled if we were not able to import wool gloves, cheese, fruit, watches or peanuts? The problem is that once an exception is made for one industry there is no stopping point. Even if some war effort were imperiled, the result would not necessarily be bad. If World War One had been a stalemate rather than a decisive allied victory, there might not have been a demand for World War Two. The oppressive Treaty of Versailles, which could not have come into existence in the absence of a decisive allied victory, was perhaps the main single reason why Hitler was able to rise to power (Taylor). ${ }^{2}$ If the war effort had been stalled to the point of stalemate because of an inability to get fruit and peanuts, World War Two might have been prevented.

Even the protection of industries that might be considered strategic could be counterproductive, causing some future war effort to be weakened. The U.S. oil industry is an example. Obviously, a shortage of oil in time of war would imperil the war effort. The solution that has been offered to avoid such a possibility is protection of the domestic oil industry. But protection does not come without costs. What are some of the effects of oil industry protection?

The restrictions the U.S. government placed on oil imports during the 1960s drained domestic reserves and increased U.S. vulnerability during the 1970s (Bradley; Willett and Jalalighajar; Cox and Wright). Furthermore, because the oil industry had to be protected, resources had to be diverted, thus weakening the domestic economy in general. If resources have to be diverted to protect dozens or hundreds of "strategic" industries, the economy would be even more seriously weakened. Refusing to protect the domestic oil 
industry -- or any industry -- would have a tendency to make it more efficient, which would have beneficial effects on national defense.

Another point that is often overlooked is that conventional wars seldom start without warning. We can see them coming. In fact, recent conventional wars such as Desert Storm, Panama, Haiti, Somalia, and so forth, have been started by the United States, which gives us even more control over events. If we can see that a war is coming, we can make preparations, such as stockpiling a few months of oil reserves. That is all the stockpile we would need, since the oil industry would be able to crank up production to wartime levels within that period of time (Plummer; Horwich and Mitchell). Of course, in the event of nuclear war, oil reserves would be the least of our worries.

The job destruction argument is another reason why Congress is prone to protect various industries. This argument basically states that failure to protect a certain industry will cause jobs to be lost. It is difficult to disagree with such a statement, since there is often ample evidence to show that jobs are indeed lost if some domestic industry is not protected.

But this argument looks at only one side of the coin. The fact is that protectionism always seems to result in a deadweight loss because the number of jobs saved by a particular tariff, quota or "voluntary" restraint agreement is always less than the number of jobs destroyed or jobs that are never allowed to come into existence because of the shift in the allocation of resources. ${ }^{3}$ One study estimated that a particular protectionist policy would save 36,000 jobs in the apparel manufacturing industry but would destroy 58,000 apparel retailing jobs, for a loss/gain ratio of more than 1.6 to 1 (Destler and Odell). Imposing voluntary restraints in the steel industry in 1984 saved 16,900 steel jobs but destroyed 52,400 jobs in industries that use steel, for a loss/gain ratio of 3.1 to 1 (Denzau 1987). Imposing a $15 \%$ import quota in the steel industry would save 26,000 steel jobs but destroy 93,000 jobs in the steel-importing industries, for a loss/gain ratio of 3.6 to 1 (Denzau 1985). A study that used the conservative 1.6 to 1 ratio estimated that the number 
of jobs saved and destroyed in the industries having more than $\$ 100$ million in annual trade volume to be 981,138 and $1,569,819$, respectively, for a deadweight loss of 588,681 jobs (McGee 1993).

The point is that even the strongest arguments in favor of protecting various industries do not hold up under analysis. Protectionism results in deadweight losses and is just a form of special interest legislation. Special interests that have influence with the legislature are feathering their own nests at the expense of the general public.

\section{Protectionist Features of NAFTA and GATT}

The time has long since passed when anyone seriously argued that tariffs are intended to raise revenue. Although tariffs do raise some revenue, the vast majority of revenue raised by the government of any developed economy is raised by an income, consumption or payroll tax (Miller 115; Coopers \& Lybrand) The main purpose of a tariff is to make it more difficult for foreign producers to sell their products in the domestic economy. Thus, any trade agreement that has tariff rates higher than zero is protectionist to some extent. NAFTA and GATT are no exception.

While NAFTA and GATT both reduced tariff rates, they did not abolish them entirely. Although NAFTA abolished some tariffs immediately, many other tariffs are to be phased out over a long phase-out period - up to 15 years in the case of NAFTA (Davis).. Thus, domestic producers can continue to receive protection into the twenty-first century. Both NAFTA and GATT are expected to result in increased trade for the United States (USITC; Schott; USGAO 1993, 1994; Hufbauer and Schott 1992, 1993). But both agreements produce suboptimal results because tariffs introduce diseconomies and have a dragging effect on economic growth because they cause resources to be misallocated and raise the price that individuals and businesses pay for both capital and consumer goods.

Both agreements produce winners and losers. In the case of NAFTA, for example, the border regions are expected to benefit substantially, whereas U.S. low-tech industries 
and labor intensive industries such as apparel, household glassware and ceramic tile, which were protected, are likely to be losers. Hufbauer and Schott estimated that NAFTA will create about 316,000 new jobs by 1995 and displace about 145,000 existing U.S. workers, for a net gain of 171,000 jobs. Opponents predicted a loss of 500,000 jobs (Davis).

NAFTA's rules of origin, or domestic content provisions (or any rules of origin, for that matter) are restrictive and can be used to penalize regional producers by forcing them to use less efficient (more costly) suppliers, which undercuts global competitiveness. Worse yet, NAFTA's rules of origin could be used as a precedent for other trade agreements, thus spreading the disease of protectionism to many future trade agreements. These rules are also complex and administratively burdensome, thus causing additional drag on the economy. These rules are expected to be most protectionist in the textile, apparel and auto industries (Hufbauer and Schott).

Mexico's auto regulations will be phased out to help auto companies that are already in Mexico. They will be able to export cars to Mexico rather than being required to make them all in Mexico. But other auto companies will not be able to export cars to Mexico for about a decade. They will have to build factories in Mexico (Davis).

NAFTA contains a number of other restrictive provisions as well. For example, the Mexican government can assert total control over investment in all aspects of the exploration, production and refining of crude oil and natural gas in Mexico (Rothbard 1993). Any party to the agreement can continue to restrict foreign investment in the fish, energy, forestry and mining industries (Rockwell 1993b). Parties can also interfere with trade that is deemed to be environmentally harmful (Anderson). Upward harmonization of environmental and labor standards also reduces competition between Canada, the United States and Mexico because of reduced incentives to invest capital.

Several protectionist deals had to be made in order to get the votes needed to pass NAFTA. Florida tomato growers received concessions, as did the Florida sugar, citrus 
and vegetable growers. The U.S. trade representative's office promised Rep. James Bacchus (D-FL) that the U.S. wouldn't cut tariffs on citrus products and vegetables that Florida farmers grow by more than $15 \%$. Deals were made with trade associations representing wheat and peanut growers. Support was obtained from the American Textile Manufacturers only because the domestic content rules require textile companies to produce fabric and yarn in North America to qualify for low tariffs. President Clinton promised legislators from Southern textile manufacturing states that he would seek a prolonged phaseout of textile quotas that protect domestic textile manufacturers from foreign competition (Davis and Calmes).

The Uruguay Round of GATT also produced a mixed bag of free trade and protectionism. While tariff rates were reduced, they were not reduced to zero. There are lengthy phase-outs, which, in effect, protect domestic producers for years to come. Quotas and voluntary restraint agreements were not abolished either, but merely limited to some extent. The antidumping rules actually made matters worse in some ways, since the irrational theories underlying antidumping are now spread to all GATT signatories. It is likely that the number of antidumping actions brought in the future will increase dramatically as a result of the new GATT rules. That is because countries that formerly did not have antidumping laws are now adopting them to conform to GATT. And antidumping laws are becoming more important as protectionist tools, since the effectiveness of tariffs and quotas has been diminished (Schott).

Agricultural supports have been reduced by $20 \%$ in the aggregate over six years. They are not industry specific, which means that governments have the flexibility to keep supports higher in favored industries. Direct payment to farmers can circumvent this support reduction. Agricultural export subsidies are to be reduced by $36 \%$ over six years, subject to exceptions. Major segments of the US and EU agriculture industries are exempt from the subsidy reduction rules, which makes the small reductions even smaller in reality. 
In some cases, a country can impose temporary duties -- special safeguards -- on certain products. These "temporary" safeguards can be imposed for four years, and can be renewed for an additional four years. The rice industries of Japan and Korea continue to be heavily protected. The sanitary and phytosanitary agreement gives countries the authority to impose trade restraints in order to protect human, animal or plant health or life. This provision may be abused by any number of domestic producers that see their market position being threatened by foreign competitors.

Some textile and apparel quotas were eliminated immediately, but many of the items covered by the Multi-Fiber Arrangement will be phased out over ten years while others will be increased. A country that is threatened by competition from a foreign country can apply safeguard measures against imports.

Tariff reductions average $38 \%$ and are to be phased-in over five years. But there are many exceptions. Some tariffs were eliminated immediately. The phase-in period for certain products is more than five years. For example, beer is subject to an eight-year phase-in and toys and paper are subject to a ten-year phase-in.

In summary, these so-called free trade agreements are not really about free trade at all. They are examples of managed trade (Hoffman and Sheehan). They allow current players to retain their protected positions well into the next century. A real free trade agreement would not create 49 new bureaucracies as NAFTA did (Rockwell, 1993a).

A real free trade agreement would only take a sentence or two. All it would need to say is that "After this date, all trade between XXX and YYY will be totally unrestricted." Better yet would be a unilateral declaration of free trade with all trading partners. It might read like this: "After this date, all trade involving XXX shall be totally free and unrestricted." There is no need for a trade agreement to be more than a few sentences long. Agreements like NAFTA and GATT, which run hundreds or even thousands of pages, are protectionist. 


\section{Conclusion}

After reviewing and analyzing the various arguments that have been put forward over the centuries to protect domestic producers it seems clear that none of them can withstand a close analysis. There is no need to protect domestic producers from foreign competition, for a variety of reasons. One of the most obvious reasons is that protectionism results in a deadweight loss. There are more losers than winners. Protectionism is a negative-sum game. Even if it were a zero-sum game, that would not be sufficient reason to justify the practice because protectionist legislation is, by its nature, special interest legislation. Domestic producers misuse government power to feather their own nests at the expense of the general public. There are also questions of rights violations, which are discussed elsewhere (Block and McGee, 1995).

NAFTA and GATT both contain protectionist features, although some portions of these agreements do reduce some trade barriers. They are a mixed bag, in that they have elements of both protectionism and free trade. In a sense, then, labeling such agreements as "free trade" agreements amounts to mislabeling and deception.

The only trade policy that benefits the general public is one of total, immediate and unilateral free trade. Such a policy is also the only one that is not suboptimal. It is the only policy that does not favor special interests (domestic producers) at the expense of the general public. 


\section{REFERENCES}

Anderson, Terry L., editor, NAFTA and the Environment, San Francisco: Pacific Research Institute for Public Policy, 1993.

Block, Walter and Robert W. McGee, "Must Protectionism Always Violate Rights?" TwentyFirst Annual Meeting of the Eastern Economic Association, New York City, March 17, 1995.

Bovard, James, The Fair Trade Fraud, New York: St. Martin's Press, 1991.

Bradley, Robert L., Jr., The Mirage of Oil Protection, Lanham, MD: University Press of America, 1989.

Coopers \& Lybrand, 1994 International Tax Summaries, New York: John Wiley \& Sons, 1994.

Corden, W.M., Trade Policy and Economic Welfare, New York: Oxford University Press, 1974.

Cox, J. and A. Wright, "A Tariff Policy for Independence from Oil Embargoes," National Tax Journal, 28, March, 1975, p. 29.

Curtiss, W.M., The Tariff Idea, Irvington-on-Hudson, NY: Foundation for Economic Education, 1953.

Davis, Bob, "Some Questions and Answers on Nafta," Wall Street Journal, November 17, 1993, A14.

Davis, Bob and Jackie Calmes, "Nafta's Odds Improve But U.S. May Reduce Its Trade Leadership," Wall Street Journal, November 17, 1993, A14.

Denzau, Arthur, How Import Restraints Reduce Employment, St. Louis: Washington University Center for the Study of American Business, 1987.

Denzau, Arthur, American Steel: Responding to Foreign Competition, St. Louis: Washington University Center for the Study of American Business, 1985.

Destler, I. M. and John S. Odell, Anti-Protection: Changing Forces in United States Trade Politics, Washington, DC: Institute for International Economics, 1987.

Ekelund, Robert B., Jr. and Robert D. Tollison, Economics, second edition, Glenview, IL and Boston: Scott, Foresman and Company, 1988.

Gable, Wayne, Myths About International Trade, Washington, DC: Citizens for a Sound Economy, n.d.

Hamilton, Alexander, Report on Manufactures (1791), reproduced in A. H. Cole, editor, Industrial and Commercial Correspondence of Alexander Hamilton, New York: Kelley; 1968. 
Hoffman, Matthew C. and James M. Sheehan, The Free Trade Case Against NAFTA, Washington, DC: Competitive Enterprise Institute, September 23, 1993.

Horwich, G. and E. Mitchell, editors, Policies for Coping With Oil Supply Disruptions, New York: Praeger, 1982.

Hufbauer, Gary Clyde and Jeffrey J. Schott, NAFTA: An Assessment, revised edition, Washington, DC: Institute for International Economics, 1993.

Kindleberger, Charles P., "International Trade and National Prosperity," Cato Journal, 3, Winter 1983/1984, 631.

Krueger, Anne O. and Baran Tuncer, "An Empirical Test of the Infant Industry Argument," American Economic Review, 75, 1982, 1142.

McGee, Robert W., A Trade Policy for Free Societies: The Case Against Protectionism, Westport, CT: Quorum Books, 1994.

McGee, Robert W., "The Cost of Protectionism: Should the Law Favor Producers or Consumers?" Georgia Journal of International and Comparative Law, 23, 1993, 529-557.

Miller, Roger LeRoy, Economics Today: The Micro View, eighth edition, New York: Harper Collins College Publishers, 1994.

Novack, Janet, "Three Yards and a Cloud of (Sugar) Dust," Forbes, September 4, 1989, 39.

Plummer, J., United States Oil Stockpiling Policy," Journal of Contemporary Studies, 4, 1981 , p. 5.

Rockwell, Llewellyn H., Jr., "Nafta vs. States' Rights," Rothbard-Rockwell Report, November 1993a, 14-16.

Rockwell, Llewellyn H. Jr., "The Teeth in Nafta's Eco-Accord," Rothbard-Rockwell Report, November, 1993b, 12-14.

Rothbard, Murray N., "Why the Pro-Nafta Hysteria?" Rothbard-Rockwell Report, November, 1993, 1-3.

Rothbard, Murray N., "Protectionism and the Destruction of Prosperity," in Llewellyn H. Rockwell, editor, The Free Market Reader, Burlingame, CA: The Ludwig von Mises Institute, 1988, 148-159.

Schott, Jeffrey J., The Uruguay Round: An Assessment, Washington, DC: Institute for International Economics, 1994.

Smith, Adam, An Inquiry into the Nature and Causes of the Wealth of Nations, 1776.

Taylor, A.J.P., The Origins of the Second World War, New York: Atheneum, 1983.

Truett, Lila J. and Dale B. Truett, Economics, St. Louis: Times Mirror/Mosby College Publishing, 1987. 
United States General Accounting Office, The General Agreement on Tariffs and Trade: Uruguay Round Final Act Should Produce Overall U.S. Economic Gains, Volume 2, July, 1994, GAO/GGD-94-83b.

United States General Accounting Office, North American Free Trade Agreement: Assessment of Major Issues, Volume 2, September, 1993, GAO/GGD-93-137B.

United States International Trade Commission, Potential Impact on the U.S. Economy and Selected Industries of the North American Free Trade Agreement, USITC Publication 2596, January, 1993.

Willett, Thomas D. and Mehrdad Jalalighajar, "U.S. Trade Policy and National Security," Cato Journal, 3, Winter 1983/1984, 721.

1 For a summary of these arguments, see McGee 1994, Chapter One.

2 For purposes of this analysis we are ignoring the Pacific Theater of World War Two, which had other causes. The reason Japan bombed Pearl Harbor was to break the blockade that F.D. Roosevelt enforced against the flow of war materiel into Manchuria, which was harming the Japanese invasion there. Our involvement in the Pacific theater of the war could have been avoided simply by minding our own business and not blockading Japan's war effort. Does anyone seriously think that Japan had plans to invade California, or that it would have been successful even if it had such plans?

3 For a summary of studies in this area, see McGee 1993. 